\title{
高速液体クロマトグラフィーによる三稙ベンゾジアゼピン㰯学体の同時測定
}

\author{
菱田 広, 竹田信也, 米島隆一, ${ }^{* 1}$ 武田明夫*2 \\ 国立名古星获院薬剂科*1

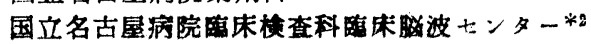

\section{High-performance Liquid Chromatographic Method \\ for the Simultaneous Quantification of \\ Three Benzodiazepines in Plasma}

\author{
HiRoshi Hishida, Shinya TAKEdA, RYUICHI Yoneshima, ${ }^{* 1}$ \\ and AKIO TAKEDA*2 \\ Department of Pharmacy,*1 and Clinical Encephalographic Center, \\ Department of Clinical Laboratory, $* 2$ Nagoya National Hospital
}

(Received February 24, 1984)

\begin{abstract}
Many benzodiazepines have valuable anticonvulsant properties. The regular monitoring of plasma concentration of benzodiazepine derivatives during treatment with the drug appears not only useful but necessary, because of the narrow therapeutic range and risk of increased occurrence of seizure in cases of overdosage.

We studied a high-performance liquid chromatographic method for the simultaneous quantification of 3 benzodiazepine derivatives in plasma. After a single extraction of the drugs from alkaline plasma, nitrazepam, clonazepam and diazepam can be resolved and quantified by using an ODS reversed phase column with 2 volumes of acetnitrile and 5 volumes of $1 \%$ triethylamine-phosphoric acid solution ( $\mathrm{pH} \mathrm{3.0)}$ as mobile phase. By adding triethylamine to mobile phase, retention time can be shortened for diazepam and the other benzodiazepines can also be separated completely. The eluted drugs were detected by their absorption at $254 \mathrm{~nm}$. With this method, it is possible to quantify as little as $6 \mathrm{ng} / \mathrm{ml}$ for nitrazepam and clonazepam, 18ng/ $\mathrm{ml}$ for diazepam with $1 \mathrm{ml}$ plasma samples. Complete chromatographic resolution of the benzodiazepines resulted, permitting quantification of all being done within $30 \mathrm{~min}$. The standard curves showed good linearity with ranges 6 to $400 \mathrm{ng} / \mathrm{ml}$ for nitrazepam and clonazepam, and 18 to $1000 \mathrm{ng} / \mathrm{ml}$ for diazepam.

The day-to-day precision, established by 10 replicate analyses, yielded CVs of 4.5 to $5.0 \%$. Analytical recovery of each drugs added to plasma was complete (95 to $99 \%$ ). The most common antiepileptics and plasma components did not intefere with the analysis.
\end{abstract}

Keywords_- high-performance liquid chromatography; benzodiazepine derivatives; nitrazepam; clonazepam; diazepam; simultaneous quantification$$
\text { はじめに }
$$$$
\text { ジアゼパム，ニトラゼパムなど，ベンゾジアゼピン誘 }
$$
尊体ははじめ抗不安薬として開発されたが, ニトラぜハ ムの抗てんかん作用が報告されて以来, 幅広いスペクト ルをもつ抗てんかん蒀として広く用いられている。また クロナゼパムはベンゾジアゼピン誘尊体であるが，抗て

$*_{1}, 8$ 名古屋市中区三の丸 4 丁目1-1；1-1, Sannomaru 4-chome, Naka-ku, Nagoya, 460 Japan
}

んかん作用を目的として開発され，最も抗てんかん作用 が強いといわれ，ジアゼパム，ニトラゼパム同様広く用 いられている.

ベンゾジアゼビン唀導体の薬物動態と臨休効果との関 連について，いくつかの報告1,2) がみられているが，他 の接てんかん萝に比べ，血清中濃度モニタリングの頻度 が少ないのは，簡缏でかつ正碓，迅速な測定法が確立さ

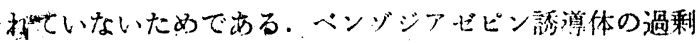

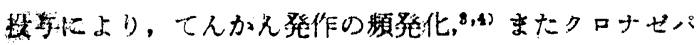


ム5) について報告されているょうに，最適血中濃度範囲 が $20 \sim 80 \mathrm{ng} / \mathrm{ml}$ で, 狭いことからも，血中薬物モニタ リングの必要がある. 同時にベンゾジアゼピン誘導体の 薬物動態および臨床効果を解明するためには，より簡便 な測定法の確立が必要である.

ベンゾジアゼピン誘導体は, これまでにラジオイムノ アッセイ,6,7) ガスクロマトグラフィー, 8 10) 高速液体ク ロマトグラフィー11 15) などによる測定報告がある・と くに高速液体クロマトグラフィーを用いた測定では, Perchalski ら ${ }^{11)}$ は順相系カラムを用いたベンゾジアゼ ピン誘導体の分離測定を報告している. しかし、ニトラ ゼパムとクロナゼパムの分離が不十分であった．また逆 相系カラムを用いた報告には, Rovei ら,12) Williams

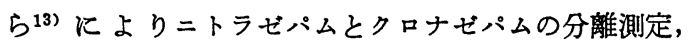
Brodie ら, 14) Kabra ら ${ }^{15)}$ とよりジアゼパムの分離測定 がある.しかしながら，三種薬物の同時測定の報告はな く, 同時測定が可能となれば, 自動試料注入装置の利用 により多数検体の処理も可能となる. そこで今回著者ら は，ベンゾジアゼピン誘導体のうち抗てんかん薬として 用いられているジアゼパム, ニトラゼパム,クロナゼパ ムの高速液体クロマトグラフィーを用いた三種同時測定 法の検討を行ったので報告する。

\section{実 験 の 部}

\section{1. 測定試料および試菜}

測定試料として当院外来患者血漿を用いた. 標準薬物 試薬としてクロナゼパム, ニトラゼパム, ニメタゼパム (日本ロシュ), ジアゼパム, デスメチルジアゼパム（武 田薬品), フェノバルビタール, フェニトイン, カルバ マゼピン(片山化学)を用いた.

\section{2. 抽出操作}

血墏試料からの薬物の抽出は, Perchalski ら ${ }^{11)}$ の方 法に基づいて行った。すなわち血墏 $1 \mathrm{ml}$ 亿内部標準 (IS) としてニメタゼパム50ngを含むアセトニトリル1

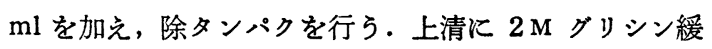

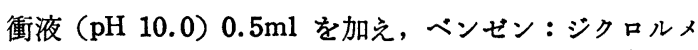
タン $(9: 1)$ 混液 $5 \mathrm{ml}$ により抽出する. 有機溶媒層 5 $\mathrm{ml}$ を濃縮乾固し, 残渣を移動相 : メタノール (1:1) 混液 $100 \mu \mathrm{l}$ 飞て溶解し, 高速液体クロマトグラフィーの 試料とした。

\section{3. 測定装而および薬物分離条件}

高速液体クロマトグラフィーのポンプは $6000 \mathrm{~A}$ 型 (Waters 製)を用い, 検出器として 440 型 UV 検出器 (Waters 製)を用い, $254 \mathrm{~nm}$ で検出した. 定量計算は 730型データモジュール (Waters製)を用い，ピーク面
積に基ついて内部標準法にて行った. 薬物分離条件とし て, カラムはラジアルパック $\mathrm{C}_{18}(8 \mathrm{~mm} \mathrm{id} \times 10 \mathrm{~cm}, 10$ $\mu \mathrm{m}$, Waters 製)を用い, 移動相は $1 \%$ \%エチルアミ ン水溶液をリン酸で $\mathrm{pH} 3.0$ 亿調整した液 5 容に対し， アセトニトリル 2 容を混ぜたものを用い, 流速 $2 \mathrm{ml} て ゙$ 分離した.

\section{4. 実験項目}

1)楽物分離条件, 2)測定の直線性と測定限界, 3)回収 率: 絶対回収率と添加回収率, 4)測定精度 : 同日再現性 と日差再現性, 以上の項目について検討した。

\section{結果}

\section{1. 莱物分離条件}

薬物フリー血清 $1 \mathrm{ml}$ 飞, ジアゼパムを200ng, ニトラ ゼパム拉よびクロナゼパムを各 60ng 添加し，抽出操作 手順に従って処理し測定試料とした. ジアゼパム, ニト ラゼパム,クロナゼパム三種薬物とす単一ピークとして 分離した. 分析時間約35分で, 保持時間はニトラゼパム 9.15 分, クロナゼバム 11.17 分, ジアゼパム 29.60 分, ニメタゼパ (IS) 16.40 分であり, 血清由来の他成分と は完全に分離した。

他の抗てんかん薬として,フェノバビタール，フェ ニトイン, カルバマゼピンを同様の方法で処理し分離し たが, 保持時間はフェノバルビタール3.55分, フェニト イン7.25分, カルバマゼピン7.40分であり, 測定妨害ピ ークとはならなかった：またジアゼパム服用患者に拈い ては, ジアせパムの代謝物であるデスメチルジアゼパム が 14.45 分飞認められたが，ニメタゼパム (IS) とは完 全に分離した。

\section{2. 直線性と測定限界}

本測定法ではFig. 2 に示すように, ニトラゼパム 0 $400 \mathrm{ng} / \mathrm{ml}$, クロナゼパム 0 400ng/ml, ジアゼバム 0 $1000 \mathrm{ng} / \mathrm{ml}$ の濃度範囲で良好な直線性を認めており, 測 定の検出限界はニトラゼパム $6 \mathrm{ng} / \mathrm{ml}$ ，クロナゼパム 6 $\mathrm{ng} / \mathrm{ml}$, ジアゼハム $25 \mathrm{ng} / \mathrm{ml}$ であった。

\section{3. 添加回収率ついて}

薬物フリー血清にニトラゼパムおよびクロナゼパムは $60 \mathrm{ng} / \mathrm{ml}$, ジアゼパムは $200 \mathrm{ng} / \mathrm{ml}$ となるようにそれぞ れの薬物を添加し，前述の前処理に従い，除タンパクお よび抽出操作を実施後, 内部標準法により薬物測定を行 った. その結果, Table 1 亿示すように, 測定を10回行 い, ニトラゼパム $95.3 \pm 5.4 \%$ ，クロナゼパム95.1 5.4 \%, ジアゼパム $99.1 \pm 8.0 \%$ という高い回収率を得るこ とができた，さらに当院外来に打いてベンゾジフゼピン 誘導体の投与を受けている患者血漿を試料とし，これに 

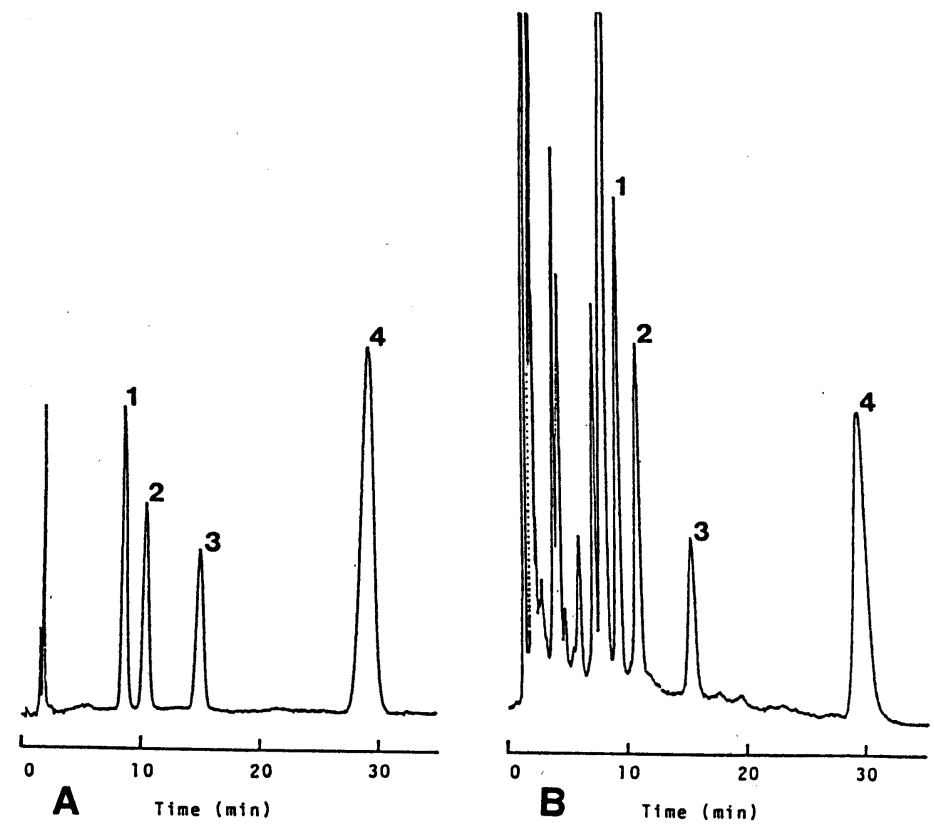

Fig. 1. Representative Chromatograms of (1) Nitrazepam, (2) Clonazepam, (3) Nimetazepam (Internal Standard) and (4) Diazepam

A. Drug standards containing nitrazepam $(60 \mathrm{ng} / \mathrm{ml})$, clonazepam $(60 \mathrm{ng} / \mathrm{ml})$ and diazepam $(200 \mathrm{ng} / \mathrm{ml})$.

B. Extraction of patient's plasma spiked with nitrazepam $(100 \mathrm{ng} / \mathrm{ml})$, clonazepam $(100 \mathrm{ng} / \mathrm{ml})$ and diazepam $(150 \mathrm{ng} / \mathrm{ml})$. patient's plasma contained phenytoin, phenobarbital, primidone and carbamazepine.
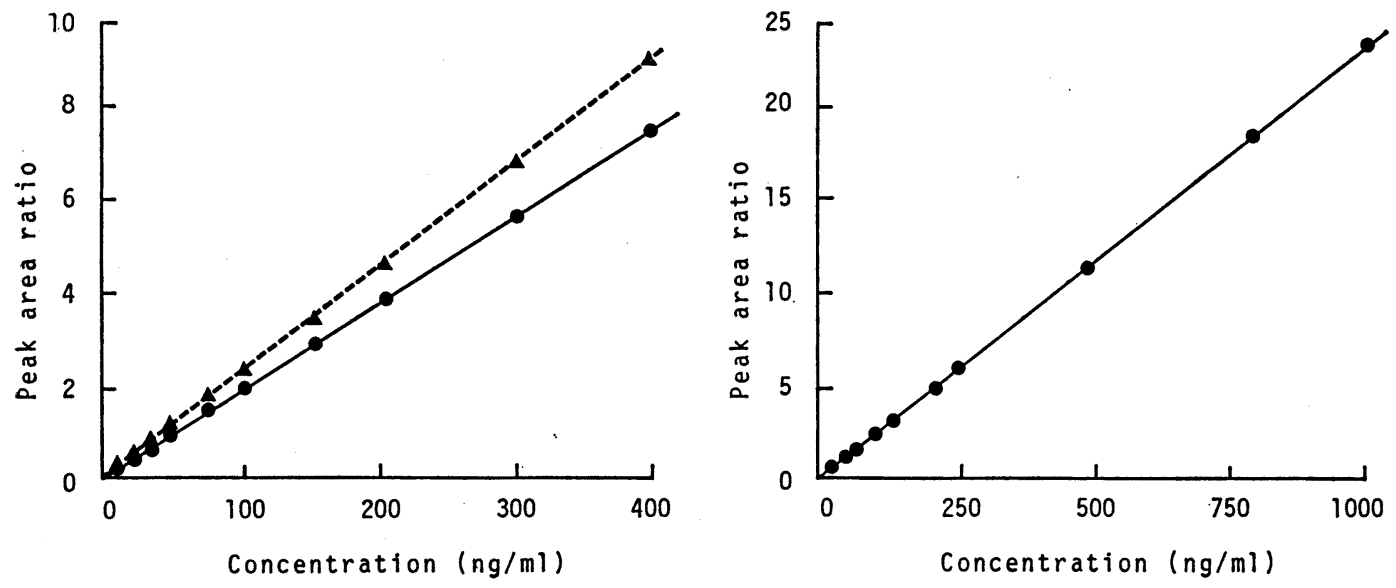

Fig. 2. Typical Standard Curves with Nimetazepam as the Internal Standard

A) for nitrazepam ( $\boldsymbol{\Delta})$ and clonazepam (O)

B) for diazepam 
Table 1. Analytical Recovery of the Analysis for Benzodiazepines

\begin{tabular}{lcc}
\hline & $\begin{array}{c}\text { Drug free serum } \\
\text { mean } \pm S D\end{array}$ & $\begin{array}{c}\text { Patient plasma } \\
\text { mean } \pm S D\end{array}$ \\
\hline Nitrazepam & $97.6 \pm 6.2$ & $95.3 \pm 5.4$ \\
Clonazepam & $98.2 \pm 6.0$ & $95.1 \pm 5.4$ \\
Diazepam & $99.3 \pm 7.3$ & $99.1 \pm 8.0$ \\
& & $N=10$
\end{tabular}

Table 2. Within-day and Day-to-day Precision of the Analysis for Benzodiazepines

\begin{tabular}{lcc}
\hline \hline & $\begin{array}{c}\text { Coefficient } \\
\text { within-day }\end{array}$ & $\begin{array}{c}\text { Variation }(\%) \\
\text { day-to-day }\end{array}$ \\
\hline Nitrazepam & 2.2 & 4.5 \\
Clonazepam & 3.9 & 4.8 \\
Diazepam & 2.8 & 5.0 \\
\hline
\end{tabular}

$N=10$

既知量の薬物を添加し，同様の操作を行った.

ベンゾジアゼピン誘導体服用患者血墏からの回収率 は, 薬物を添加した試料の測定値から薬物未添加試料の 測定值を差し引き, 添加薬物量の回収率として算出し た. 各薬物とる10試料の測定を行い, ニトラゼパム97.6 $\pm 6.2 \%$ ，クロナゼパム $98.2 \pm 6.0 \%$ ，ジアセ゚ム $99.3 \pm$ $7.3 \%$ の結果を得た.

\section{4. 測定精度}

薬物フリー血清に, ニトラゼパムおよびクロナゼパム は $60 \mathrm{ng} / \mathrm{ml}$, ジアゼパム $200 \mathrm{ng} / \mathrm{ml}$ の濃度になるように 薬物を添加して測定試料とし，測定精度を検討した．測 定の同日再現性は, 各薬物を同日内に10回測定し，また 日差再現性は，各薬物を10日間にわたり毎日測定した. 同日再現性の CV 值は Table 2 に示すように, ニトラ ゼパム $2.2 \%$ ，クロナゼパム $3.9 \%$ ，ジア゙パム $2.8 \%$ で あり, 日差再現性の CV 值は，ニトラゼパム $4.5 \%$ ，ク ロナゼパム $4.8 \%$, ジアゼパム $5.0 \%$ と良好な結果が得 られた。

\section{考摹}

アセトニトリルとリン酸緩衝液の二成分移動相による 各種抗てんかん薬を含む検体の薬物分離は完 全ではな い.たとえばジアぜパムの保持時間を短縮すると，ニト ラゼパム,クロナゼパムのみならずカルバマゼピンなど の比較的保持時間の短い薬物については, まったく分離
することができない. そこで残留しているシラノール基 の影響を抑制する目的で用いられているトリエチルアミ ンの添加を試みた.このトリェチルアミンの添加により, ジアゼパムの保持期間が，トリエチルアミンを添加しな い条件に比べ，約半分に短縮可能となり，乙かも比較的 早く流出してくるニトラゼパム，クロナゼパムの完全な 分離も可能であった. すなわちトリェチルアミンの添加 により，他成分の分離を損なうことなく，ジアぜハムの 保持時間の短縮が可能となり, 分離時間35分で, 血漿成 分, 他薬物, その代謝物の測定妨害もなく, 三種ベンゾ ジアゼピン誘導体の同時測定が可能となった．順相系カ ラムを用いた Perchalski ら11)，また逆相系カラムを用 いた Rovei ら ${ }^{12)}$ の報告にもあるように，カルバマゼピ ンの血漿中濃度が高いと, カルバマゼピンとニトラゼパ ム, クロナゼパムとの分離ができないこと，またジアゼ パムの代謝物であるデスメチルジアゼパムと内部標準と して用いているニメタゼパムとの分離ができなくなるこ とから，これ以上の分離時間の短縮は不可能であった。 また移動相の $\mathrm{pH}$ が 3.0 以上となると, 保持時間が長く なる傾向があり, 移動相の $\mathrm{pH}$ を 3.0 とした.

測定の回収率に関しては, 三種薬物とも薬物フリ一血 清での添加回収率は，内部標準法により測定を行ってい ることからも，97.6～99.3\%と非常に良好であり，Perchalski ら11) の報告よりもすぐれた結果であった。 今 後, 前処理カラムの利用により, 前処理操作上の抽出効 率を高め，測定限界がさらに低下するよう検討を加えた い. またベンゾジアゼピン服用患者血漿での添加向収率 は，95\%以上と良好な結果を得ているが，ジアゼパム おいては 8.0\%の変動を認めている。これはジアゼパム の保持時間が長い影響がでているものと考えるが，臨床 上での問題とはならない，また測定精度においては，同 日再現性と日差再現性をみている.三種薬物ともその $\mathrm{CV}$ 值は同日再現性では $4 \%$ 以下，日差再現性では $5 \%$ 以下であり, Perchalskiら11)の報告とほぼ同様な值であ り，再現性もすぐれた測定法であると考える．同一分離 条件で, 三種ベンゾジアゼピン誘導体の測定が可能とな り，特に自動試料注入装置を含めた高速液体クロマトグ ラフィーであれば, 多数検体の処理も可能となり, 非常 に有用な測定法であると考える。また今後，前処理カラ ムなどの利用により, 抽出, 濃縮操作の必要もない全自 動の測定が可能となるよう検討を加えたい。

的辞 本研究のために試薬を提供していただいた日本 ロシュ株式会社, 武田薬品工業株式会社に深謝いたしま す. 


$$
\text { 文䘞 }
$$

1) B. Mikkelson, P. Berggreen, P. Joensen, O. Kristensen, O. Kфhler, B. O. Mikkelsen : Epilepsia, 22, 415 (1981).

2) 三浦寿男 : 神経精神薬理, 2, 505 (1980).

3) P. L. Morsell : "Drug Disposition During Development," Spectrum Publication Inc., 1977, pp. 3-40.

4) P. L. Morselli : “Neuropsychopharmacology," Pergamon Press, 1978, p. 877.

5) J. K. Penry: "Drug Interactions," Raven Press, 1974, p. 299.

6) W. R. Dixon, R. L. Young, A. Liebman : J. Pharm. Sci., 66, 235 (1977).

7) W. R. Dixon, R. L. Young, A. Liebman : Pharmacologist, 17, 251 (1975).
8) P. M. Edelbroek, F. A. De Wolff : Clin. Chem., 24, 1774 (1978).

9) J. P. Cano, J. Guintrand, C. Aubert, A. Viala. : Arzeneim. Forsch., 27, 338 (1977).

10) J. P. Cano, J. Catalin, A. Viala, J. Roger, C. A. Tassinari, C. Draved, H. Gastaut : Eur. J. Toxicol. Environ. Hyg., 9, 213 (1976).

11) R. J. Perchalski, B. J. Wilder : Anal. Chem., 50, 554 (1978).

12) V. Rovei, M. Sanjuan : Therapeutic Drug Monitoring, 2, 283 (1980).

13) R. C. Williams, J. L. Viola : J. Chromatogr., 185, 505 (1979).

14) R. R. Brodie, L. F. Chasseaud, T. Taylor : J. Chromatogr., 150, 361 (1978).

15) P. M. Kabra, G. L. Stevens, L. J. Marton : J. Chromatogr., 150, 355 (1978).

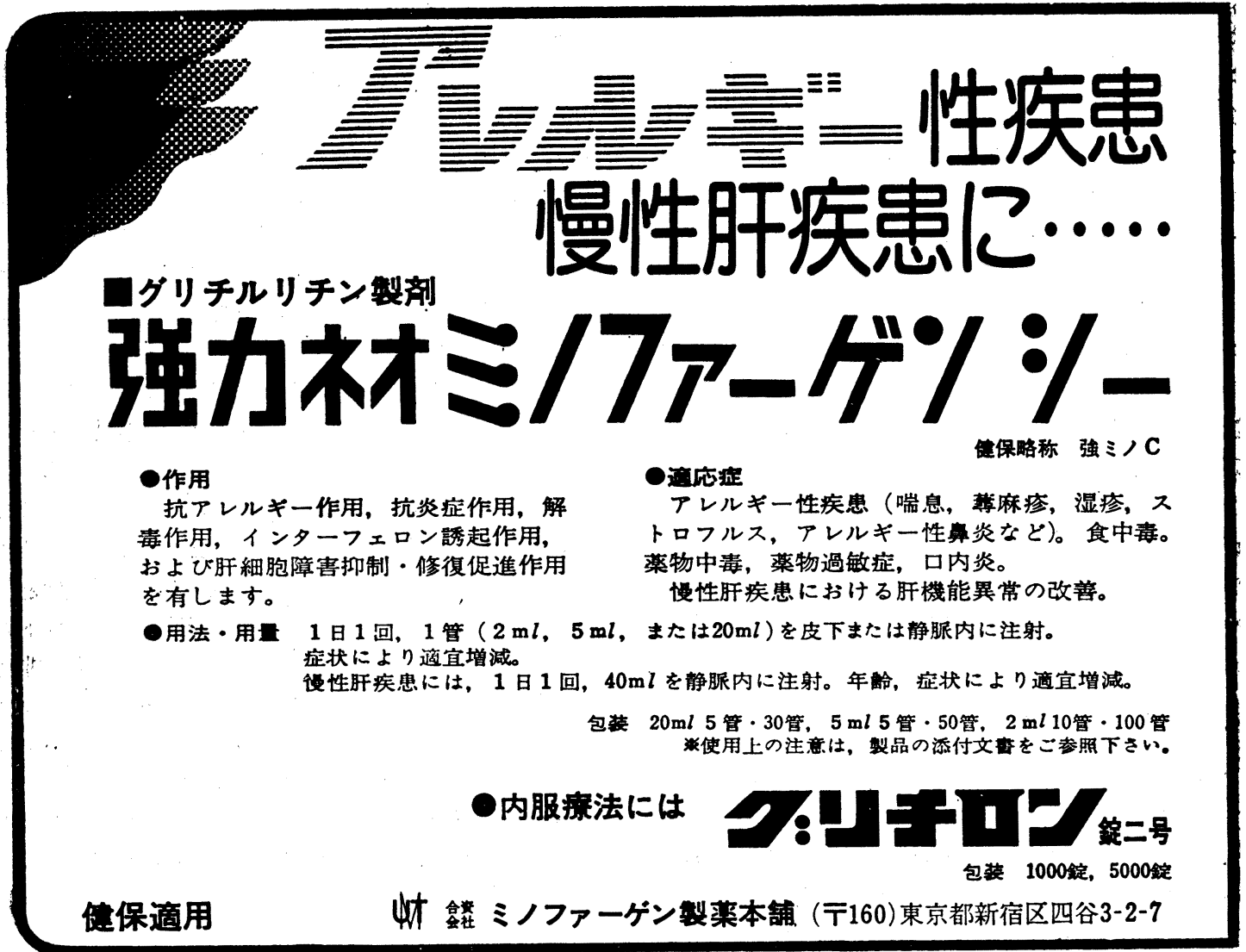

